\title{
An Investigation into the Sources of Fluctuation in Real and Nominal Wage Rates in Eight EU Countries: A Structural VAR Approach
}

\author{
by \\ Tomoe Moore \\ Coventry Business School, Coventry University \\ Coventry, CV1 5FB, UK \\ E-mail: t.moore@coventry.ac.uk \\ and \\ Eric J. Pentecost \\ Department of Economics, Loughborough University \\ Loughborough, Leicestershire, LE11 3TU, UK \\ E-mail: e.j.pentecost@lboro.ac.uk
}

Revised version

January 2006 


\title{
An Investigation into the Sources of Fluctuation in Real and
}

\section{Nominal Wage Rates in Eight EU Countries: A Structural}

\section{VAR Approach}

\begin{abstract}
This paper uses the SVAR approach to assess the degree of labor market flexibility measured as the responsiveness of real and nominal wages to permanent and temporary shocks - in eight EU member states (France, Italy, UK, Netherlands, Poland, Hungary, Slovakia and the Czech Republic) with a view to assessing their suitability for Euro-area membership. It is found that for Hungary and the Czech Republic real wages are more responsive to real (permanent) shocks than some current members of the Euro zone, such as Italy. On the other hand, in Poland and Slovakia, real wage flexibility seems to be extremely low, making higher unemployment more likely than other EU countries and early euro-area membership unadvisable.
\end{abstract}

JEL Classification Nos: E3, J30, J60, F02

Keywords: Nominal and real wage flexibility, structural VARs, transitory and permanent shocks 


\section{Introduction}

One of the criteria for membership of an optimum currency area is that of labor market flexibility. Labor market flexibility can be considered to consist of two aspects: aggregate real wage flexibility and institutional flexibility. Aggregate real wage flexibility determines the overall balance of supply and demand in the labor market and is important if high levels of employment are to be maintained in a monetary union, since it is a substitute for the adjustment of the nominal exchange rate and an independent monetary policy. Institutional flexibility, on the other hand, is based on the institutional features of the national labor markets - such as minimum wage legislation, the design of the tax and benefit system and social protection schemes in operation - and may also serve to support labor market adjustment to shocks. In this paper we assume that the institutional features as given and focus on nominal and real wage flexibility. This is because labor market reform has been very slow and so over a relatively short period of a decade there have been very few significant changes in the institutional structure of EU labor markets and also because in part such institutional changes are likely to be reflected in greater wage flexibility.

The flexibility of the real wage rate is generally thought to be an important element of labor market flexibility. The traditional approach to examining labor market flexibility is to estimate a Phillips curve (Pentecost and Sessions 2002) or a wage curve (see Card, 1995 for a survey), which link the rate of unemployment to the rate of change in money wages or the level of the money wage rate, respectively. This research shows that unemployment-wage elasticities differ across countries and change over time. Much of the work done in the 1980s gives a wage-unemployment elasticity of about -0.10 , but recent work by Montuenga-Gomez et al (2003), discover higher elasticities for France and Italy of -1.80 and -0.60 , respectively. Recent work 
on the wage curve for the Central and Eastern European countries (CEECs), suggests that although wages react more strongly to regional unemployment developments in the CEECs than in the developed EU member states, they are slightly less responsive to national unemployment rates (Huber, 2004) ${ }^{1}$.

These studies of the wage curve suffer from the serious limitation that they do not explicitly take account of the equilibrating mechanisms in the labor market, whereby the demand for and supply of labor functions adjust to various real and nominal shocks. It follows that real wage movements are a function of the shocks that buffet the demand and supply of labor relations and that real wage flexibility (or rigidity) needs to be measured in a way, which would predict how much wage flexibility would result from a given shock. Andersen and Toulemonde (2002), for example, using a theoretical, dynamic macroeconomic model with imperfect competition, show that temporary shocks are consistent with little real wage responsiveness and large employment responsiveness, while permanent shocks to productivity largely affect real wages and not employment.

The principal contribution of this paper is to investigate the degree of aggregate real and nominal wage flexibility following real and nominal shocks using the structural VAR (SVAR) analysis of Blanchard and Quah (1989) on eight EU member states from the mid-1990s to date. The decomposition of shocks into real and nominal shocks is accomplished by imposing a long-run neutrality restriction such that nominal shocks have no long-run effect on the real wage rate. This restriction is consistent with the natural rate hypothesis of neo-classical economic theory. Thus permanent (real) shocks should have a permanent effect on the real wage rate, whereas temporary (nominal) shocks should have only transitory effects. This decomposition is also useful to gauge the effectiveness of monetary policy in the 
various economies, since a large transitory component in the real wage due to nominal shocks may indicate a high degree of nominal inertia in prices, which enables policymakers to influence the real wage rate. As far as the new EU member countries are concerned any such influence of monetary policy on the real wage rate will be lost on membership of the euro-zone. Thus the finding of little price inertia in the new EU member states following a nominal shock is a necessary, albeit not a sufficient condition, for membership of EMU not to result in higher unemployment.

The rest of this paper is set out as follows. Section 2 sets out a neo-classical model of the aggregate labor market, with a view to providing an economic rationale for the statistical identification of transitory and permanent shocks in Section 3. Section 4 considers the data set and the various time series statistical tests. Section 5 examines the empirical results with regards to the effects of transitory and permanent shocks on nominal and real wage rates, while Section 6 briefly considers the consistency of these results with unemployment trends in the countries concerned. Section 7 concludes with an assessment of the policy implications.

\section{The Theoretical Underpinnings}

Although there are a large number of alternative models of the aggregate labor market, there seems to be a general consensus that permanent (real) productivity shocks permanently raise the real wage rate and temporary (nominal) shocks do not. For clarity this section therefore focuses on the neo-classical model of the labor market to motivate the empirical model, but the qualitative essence of the results generalise to a wider class of labor market models, including models which are based on some form of imperfect competition ${ }^{2}$. 
In the neo-classical labor market model it is assumed that there is perfect competition and that the real wage rate is set equal to the marginal productivity of labor. Thus if the production function is given by $y=f(N)$, where $y$ is output and $N$ is the labor input, the real wage rate $(W / P)$ is equal to:

$$
W / P=f^{\prime}(N)
$$

where $f^{\prime}(N)>0$ is the marginal product of labor. Given the usual conditions of diminishing marginal product of labor, the demand for labor curve has a negative slope in real wage - employment space, as shown in Figure 1. Following Heijdra and Van Der Ploeg (2002), the supply of labor is assumed to be a positive function of the expected real wage rate, such that

$$
W / P^{e}=g(N) \quad \text { or } \quad W / P=\left(P^{e} / P\right) g(N)
$$

where $W / P^{e}$ is the expected real wage and the function $g(N)$ represents the aggregate preferences of the households for work or leisure. Households' preferences for work are assumed to be positively related to the expected real wage rate, so that $g^{\prime}(N)>0$, where the substitution effect of work for leisure, in response to rise in the real wage, is assumed to dominate the income effect. Multiplying both sides of (2) by the ratio of expected prices to actual prices $\left(P^{e} / P\right)$, enables the aggregate supply of labor to be drawn as a positive function of the actual real wage rate, as the second expression in (2) shows.

These demand and supply relations are shown on Figure 1, where the market clearing real wage rate is $\mathrm{w}_{0}$ and the equilibrium level of employment is at $\mathrm{N}_{0}$. Permanent (real) shocks affect the market through the $g(N)$ or $f^{\prime}(N)$ functions. A rise in productivity, for example, is a real shock that shifts the demand function up, 
raising the real wage rate and employment. Thus a positive permanent shock is reflected in a permanent rise in the real wage rate, to $\mathrm{w}_{1}$, in Figure 1.

On the other hand, a transitory (nominal) shock is defined as a rise in the aggregate price level, $P$, as a result of a change in monetary policy. This will only affect the supply of labor curve temporarily, until price level expectations (and the nominal wage rate) are revised upwards and the supply of labor curve moves back to its initial position. In this case the rise in the nominal wage rate is permanent, but the change in the real wage only temporary. In fact the real wage may temporarily rise or fall following a nominal shock, depending on the relative stickiness of nominal wages and prices (see, for example, Spencer, 1998). Suppose the rise in $P$ surprises workers then, real wages will temporarily fall as it takes time for workers to adjust their price expectations (and money wages) upwards. This relative 'stickiness' in money wages means that the real wage rates move counter-cyclically. On the other hand, if workers over anticipate future price rises as a result of nominal shocks, then price level expectations, $P^{e}$ and money wages may rise ahead of the actual price level. In this case the real wage will temporarily rise, pro-cyclically with the transitory shock ${ }^{3}$. Finally, if agents are assumed to have perfect foresight expectations then the permanent rise in the nominal wage rate would occur simultaneously with the rise in the price level and there would be no temporary impact on the real wage or the level of employment.

Thus from this model temporary shocks emanating from aggregate demand lead to permanent changes in the nominal wage rate and no permanent effect on employment or the real wage, whereas permanent shocks to productivity lead to permanent rises in both the real and nominal wage rate and also to higher equilibrium employment. A permanent, positive shock to labor supply will also have the effect of 
permanently lowering the real wage rate and raising the level of equilibrium employment.

The empirical decomposition of economic shocks in the next section is, however, unable to distinguish between permanent demand shocks and supply shocks, only between hypothetical permanent (real) and transitory (nominal) shocks. However, to the extent that the empirical analysis shows the real wage falling following a permanent shock, then this maybe interpreted as a shift to the right in the labor supply function, ceteris paribus. Given the large structural changes that the economies of Central and Eastern Europe have experienced since the early 1990s, however, it seems rapid productivity growth, brought about by market liberalization, the adoption of new technology and improved management efficiency (Eilat and Zinnes, 2002), is more likely to be the primary real shock affecting these labor markets. Temporary shocks, on the other hand, may be identified with aggregate demand disturbances, due to changes in monetary, and in many cases, exchange rate policy. In the Western European economies temporary (nominal) shocks could reflect the move towards inflation targeting during the 1990s and the preparation for the introduction of the Euro, whereas in the CEECs these temporary shocks might also include the impact of the removal of capital controls, which have lead to appreciation of the exchange rate (Brada, 1998) as well as fiscal imbalances left over from the transition process (Desai, 1998).

\section{The Empirical Identification of the Shocks}

It is assumed that there are two uncorrelated structural shocks driving the model:

nominal shocks and real shocks. Suppose that the vector $\Delta x_{t}=\left[\begin{array}{lll}\Delta r w_{t} & \Delta n w_{t}\end{array}\right]$ is stationary, where $r w_{t}$ is the logarithm of real wages, $n w_{t}$ is the logarithm of the 
nominal wages ${ }^{4}$ and $\Delta$ is the first difference operator. It is assumed that $\Delta x_{t}$ is explained by the linear dynamic structural model (Lastrapes, 1992):

$$
\Delta x_{t}=B_{o} \Delta x_{t}+B_{1} \Delta x_{t-1}+\ldots . .+B_{q} \Delta x_{t-q}+u_{t}
$$

In order to normalise, zero restrictions are imposed on $B_{o}$ and the residual covariance, such that:

$$
B_{o}=\left[\begin{array}{cc}
0 & b_{02} \\
b_{03} & 0
\end{array}\right] \text { and } E\left(u_{t} u_{t}^{\prime}\right)=\Omega=\left[\begin{array}{cc}
\phi_{11} & 0 \\
0 & \phi_{22}
\end{array}\right]
$$

$B_{1}, \ldots, B_{q}$ are unrestricted parameter matrices. The data can be recovered only in the unrestricted reduced form of the structural model (3), such that

$$
\Delta x_{t}=\left(I-B_{o}\right)^{-1} B_{1} \Delta x_{t-1}+\ldots+\left(I-B_{o}\right)^{-1} B_{q} \Delta x_{t-q}+\left(I-B_{o}\right)^{-1} u_{t}
$$

where $u_{t}$ is white noise and contains two fundamental structural shocks. Re-writing equation (4) gives:

$\Delta x_{t}=\Gamma_{1} \Delta x_{t-1}+\ldots+\Gamma_{q} \Delta x_{t-q}+\varepsilon_{t}$

where $E\left(\varepsilon_{t} \varepsilon_{t}^{\prime}\right)=\Sigma=\left[\begin{array}{ll}\sigma_{11} & \sigma_{12} \\ \sigma_{21} & \sigma_{22}\end{array}\right]$

Equation (5) is the VAR representation of $\Delta x_{t}$. From the reduced form, $\Gamma_{1}, \ldots . \Gamma_{q}, \Sigma$ and $\varepsilon_{t}$ can be obtained. It follows that the effects of the structural shocks $u_{t}$ on $\Delta x_{t}$ can be ascertained if $B_{o}$ and $\Omega$ are identified from the VAR estimates. From (3), (4) and (5), we have

$$
\Sigma=\left(1-B_{0}\right)^{-1} \Omega\left(1-B_{o}\right)^{-1^{\prime}}
$$

The identification problem arises in that there are four unknown parameters $\left(b_{02}, b_{03}, \phi_{11}\right.$ and $\left.\phi_{22}\right)$ to be identified, but estimation yields only three independent pieces of information $\left(\sigma_{11}, \sigma_{12} \text { and } \sigma_{22}\right)^{5}$. This means that one additional restriction 
on $B_{o}$ or $\Omega$ is needed for identification. The additional restriction imposed in this paper is the long-run neutrality of nominal shocks on the real wage rate. This is consistent with the natural rate of unemployment hypothesis.

It needs to be clarified how the additional restriction in the SVAR model can be reconciled with the different sources of wage rate fluctuations. It is convenient to see the final form of $\Delta x_{t}$ as an infinite moving average representation of the reduced from. This expresses the dependent variables as a function of the exogenous shocks, such that

$$
\Delta x_{t}=\left(I-\Gamma_{1} L-\Gamma_{2} L^{2}-\ldots \ldots-\Gamma_{q} L^{q}\right)^{-1} \varepsilon_{t}
$$

Alternatively, it can be expressed as:

$\left.\left[\begin{array}{c}\Delta r w_{t} \\ \Delta n w_{t}\end{array}\right]=\left[\begin{array}{ll}A_{11}(L) & A_{12}(L) \\ A_{21}(L) & A_{22}(L)\end{array}\right] \begin{array}{l}\varepsilon_{1 t} \\ \varepsilon_{2 t}\end{array}\right]=A(L) \varepsilon_{t}$

where $A_{i j}$ are polynomials in the lag operator, $L$. The time paths of the effects of the various shocks on the real and nominal wage rates are implied by the coefficients.

The two residuals in equation (4) have effectively been transformed into the two shocks, $\varepsilon_{1 t}$ and $\varepsilon_{2 t}$ in equation (7b). Consider two types of orthogonal shocks, each of which could be the source of variation in the observed movements in real and nominal wage rates. $\varepsilon_{1 t}$ is assumed to reflect changes in endowments, productivity and technology. This shock may affect both the real and nominal wage rates in the short and long run. On the other hand, $\varepsilon_{2 t}$ is caused, for example, by nominal money supply shocks or a devaluation of the exchange rate. Nominal shocks are assumed to have only temporary effect on the value of the real wage rate but may have permanent effects on the nominal wage rate. The assumption of the temporary effect on the real wage rate acts as the identifying restriction (see, for example, Enders and Lee, 1997). 
The long-run neutrality of nominal shocks is represented by the restriction that the sum of the coefficients in $A_{12}(L)$ is zero, i.e. $\quad \sum_{j=0}^{\infty} a_{12}(j)=0$, where $a_{12}(j)$ is the $j$ th coefficient in $A_{12}(L)$, or the effect of $\varepsilon_{2}$ on $\Delta r w$ after $j$ periods. $\sum_{j=0}^{\infty} a_{12}(j)$ is the cumulative effect of $\varepsilon_{2}$ on $\Delta r w$ over time, and that the long-run effect of $\varepsilon_{2}$ on $\Delta r w$ is zero. The restriction that aggregate demand has no long-run impact on the log of real wages is imposed and follows from the assumption that the natural (equilibrium) rate of unemployment hypothesis holds in the long run.

\section{The Data Set and Preliminary Data Analysis}

The data are monthly observations from January 1993 to February 2004 for France, Italy, Netherlands and the UK and from January 1995 to December 2003 for the Czech Republic, Hungary, Poland and Slovakia. Hourly wage rates are used for France, Italy and Netherlands, whereas weekly earnings are used for the UK. Monthly earnings are used for the new accession economies. The wage rates are taken from OECD (Main Economic Indicators), except France (from IMF). The consumer price indices (CPI) from IFS are used for prices. All variables are seasonally unadjusted.

The logarithms of real and nominal wages for the eight countries are shown in Figure $2^{6}$. With the exception of Italy, the time series for real wages have upward trends. The real wage series in Italy falls by about 3 per cent over the sample period and the real wage increase in the Netherlands is only about 4 per cent over the sample period. In comparing the developed and transition countries, Figure 2 indicates that the real wage growth has been much faster in the transition economies, ranging from 60 per cent in Poland to 30 percent in Slovakia compared to just 18 per cent in the UK 
and 15 per cent in France. This most likely reflects the degree of structural change, including the liberalization of prices in the new accession countries in early stage of the transformation process (see, for example, Fardmanesh and Tan, 2003 and Papazoglou and Pentecost, 2004).

For the moving average representation of equation (5) to exist, however, requires that the vector process $\Delta x$ is stationary, and that there is no cointegration between $r w$ and $n w$. These wage series are, therefore, tested for unit root processes and cointegration relationships. The results are presented in Table 1. The ADF test statistics indicate that a unit root cannot be rejected for either real or nominal wage rates and therefore $r w$ and $n w$ are non-stationary processes. The KPSS tests (Kwiatkowski et al 1992) also confirm that stationarity is rejected at the 5\% significance level, in all except three cases: $n w$ of UK and $r w$ of Czech Republic and Italy. The stationary of the UK nominal wage series and the real wage series of the Czech Republic is not rejected at a 5\% significance level, but is rejected at a $10 \%$ level on the KPSS test. In the case of real wages for Italy, the coefficient on the trend is significant, so it is reasonable to treat the KPSS test result with the trend as the appropriate result, in which case the levels of Italian real wage rates are nonstationary. Overall the results suggest that the time series of the logs of real wages and nominal wages for all countries can be regarded as non-stationary. The Engle-Granger (1987) cointegration test results are also presented in Table 1 and show an absence of cointegration between real and nominal wage rates. This implies that there is no linear, long-run equilibrium relationship between them and so validates the bi-variate SVAR model specified in Section 3.

The lag lengths in the bi-variate VAR are determined by starting with a maximum of 16 lags and then testing down using including the Akaike and Schwartz 
information criteria to select the lag length where there is no evidence of serial correlation according to the likelihood ratio test. Thus the lag lengths are between 11 and 14 months for the countries in this sample, as shown in Table 2. Because of the pronounced wage spikes in Figure 2, rather than specifying seasonal dummies uniformly, monthly specific dummies are tested for significance month by month in the VAR. The monthly dummies are included if they are significant at the 10 per cent level in at least one of the equations. The inclusion of the trend is determined in a similar way.

In addition, in order to examine the possibility of exogenous shifts in the variables, the significance of specific-event dummies were also tested by the Chow's structural break test using a likelihood ratio statistic ${ }^{7}$. The specific-event dummies include the Asian-Russian crises in 1997 and 1998, and the policy change to inflation targeting taken in Poland and the Czech Republic in 1998. The dummy for the switch to inflation targeting in Poland and the Czech Republic is statistically significant. It is also evident from the plots of real and nominal wages, which seem to exhibit a structural break in 1998.

The impact of the Asian and Russian crises is not rejected in the Czech Republic and UK equations, although the timing of the Asian-Russian crises coincided with a currency crises in the Czech Republic and a switch to a floating exchange rate policy. The structural break test therefore captures both the internal and external exogenous shifts for the Czech Republic, although it is likely that the break in the Czech Republic is more due more to the internal financial crisis rather than to external factors. Table 2 presents the VAR model specification based on these tests. Accordingly the period and policy shift dummies are specified in the VAR as deterministic variables together with the monthly and trend dummies where 
appropriate. The fully specified VAR is estimated followed by the imposition of the restriction of long-run neutrality in order to identify the real (permanent) and nominal (temporary) shocks.

\section{Empirical Results}

Figures 3 and 4 display respectively, the impulse response functions (IRFs) of real and nominal wage rates to both real (permanent) and nominal (temporary) shocks. Each plot shows the dynamic response of the wage rate to one standard deviation innovations in real (permanent) or nominal (transitory) shocks over forecast horizons from 1 to 48 months. Because the first difference of each series is stationary and the impulse response functions die out, the figures are drawn for the logarithmic levels of the wage rates.

Figure 3 shows that the impulse response functions for real wages reveal that the shocks are generally well-identified with the responses consistent with the theoretical priors, in that the real wage response to a positive real shock is positive and permanent, although with some initial overshooting in the case of the Czech Republic, Hungary, Poland and to a lesser extent, the UK. Thus there appears to be a common feature between the Euro area countries and the non-Euro area countries, in that the IRF tends to be more volatile over the time horizon of four years in the noneuro member states, such as the transition economies and UK, while in France, Italy and Netherlands given a real shock, the real wage converges slowly to the long-run equilibrium level with a gently curved profile. In the case of the non-euro member states, the long-run level is achieved only after relatively volatile fluctuations, but often more quickly in about two years, compared to four years for the euro-area countries. 
The magnitude of the real wage responses to the permanent shock differs between developed and transition economies, in the case of the former it ranges from $0.2 \%$ to $0.6 \%$, whereas in the case of the latter, from $0.3 \%$ to $2.4 \%$. It is, therefore, evident that the effects of real shocks on real wages in the CEECs are in general larger than those in the developed European Union (EU) economies. This finding is consistent with the more rapid increase in real wages for transition countries (Figure 2).

The effects of a transitory shock indicate some cyclical behaviour in real wages, which is potentially an indicator of the driving force behind business cycles (Gamber and Joutz, 1993 and Spencer, 1998) although this is more pronounced for some countries, such as the UK and the Czech Republic, than for others such as France and Slovakia. In France and Slovakia there is little cyclical variation after about two years, whereas for other countries the real wage rate is either still declining after about four years (Italy and the Netherlands) or fluctuating (the Czech Republic, Hungary and the UK).

In general Figure 3 also shows that a positive transitory shock increases real wages in the short run, apart from in Slovakia. This implies that aggregate demand disturbances and real wages are positively correlated in the short run. Increases in demand are met by corresponding increases in output. This requires an increase in labor inputs, which requires an increase in the nominal wage rate, provided the labor supply curve is positively sloped. Thus wages tend to rise ahead of prices and hence a positive aggregate demand shock is associated with an increase in real wages (also see, for example, Spencer, 1998). Thus pro-cyclical real wages would indicate that nominal wages move ahead of prices over the cycle and is taken as evidence that relatively sticky prices have played a more important role than sticky wages in 
transmitting aggregate demand shocks to real economic activity in the these EU countries. The only exception is Slovakia where the positive transitory shock decreases the real wage. Aggregate demand disturbances and real wages are more likely to be negatively correlated where money wages are relatively sticky compared to prices, as the neo-classical model of Section 2 demonstrates.

The effect of a nominal shock on the real wages dies out over time, reflecting the identification restriction of long-run neutrality. In general, as compared with the real shock, the real wage is less sensitive to the nominal shock, but with the exception of the Netherlands and Slovakia, where an initial positive response is followed by a sharp decline, before returning, partially or fully, to the initial level.

The evidence provides a useful indication that joining the single currency may lead to more stability in the wage structure in the face of real and nominal shocks. This, however, does not necessarily imply that the fixed exchange rate regime is more effective rather than the floating regime in stabilising the wage structure ${ }^{8}$. In the EU, the individual member states face increased competition in product markets and this induces a more similar wage development and stronger wage interdependencies. This situation could be further accelerated in the monetary union leading to the convergence of real wages among the EU nations, and this may be reflected in the IRFs for France, Italy and Netherlands being relatively stable ${ }^{9}$.

Figure 4 shows that nominal wage rates all initially respond positively to a nominal shock, swiftly followed by a sharp decline and then a gradual convergence back to equilibrium, with the exception of the Netherlands where there is little or no decline. The pattern of nominal wage rates is very similar for a real shock: an initial rise followed by a sharp fall and then a steady path back towards equilibrium. An interesting result is that for the UK the path of nominal wages is very similar 
regardless of the nature of the shock, suggesting that money wages are more flexible than prices.

Table 3 reports the variance decompositions (VD), which measure the relative contribution to the forecast error variance of each shock as a function of the forecast horizon, of real wages at selected horizons. The contribution of the nominal shock is not presented, but is given by $100 \%$ minus the contribution of the real shock. For most countries, with the exceptions of Hungary, Italy and Poland, at all time horizons the real shock accounts for most of the variance of the real wage with the contributions ranging from over $60 \%$ to $98 \%$. In the case of Hungary the contribution of real shock exceeds that of nominal shock up to the 6-month horizon. This is consistent with the theoretical expectation that real shocks are more important for real wage rate adjustment ${ }^{10}$. For example, an improvement in technology that raises the efficiency of production may increase the demand for labor, raising the real wage. This has important implications for membership of EMU. Within EMU, there is little scope for demand management so the labor markets must be able to adjust to permanent shocks, thus any adverse real shock must be absorbed by wages adjusting to the new equilibrium level (Huber, 2004).

The results for Italy and Poland are in sharp contrast to those of the other countries, because the real shock explains only $1.45 \%$ to $36 \%$ of the variance in real wages. With the real wage rate not adjusting to real shocks, when faced with adverse real shocks unemployment is likely to rise by more in these economies than in those economies with more responsive real wages, and thus these countries are not good candidates for EMU entry. This is broadly consistent with the results of Dibooglu and Kutan (2001) for Poland and Hungary, where over the period from 1990 to 1999 using monthly data, real shocks were found to play a significant role in explaining 
real exchange rate fluctuations for Hungary, whereas such a significant role of real shocks was not observed for Poland. There is some evidence to support the different contribution of real shocks on real wages in Poland and Hungary, in that over the period 1995 to 1997 real wage increases have exceeded productivity gains for Poland, whereas Hungary enjoyed productivity gains above real wage increases (Dibooglu and Kutan, 2001).

Moreover, in a recent study Kempa (2000) finds that for France, Italy, Netherlands and the UK, for exchange rates over the sample period 1972:1 to 1996:4 (quarterly data), the results are broadly consistent with our findings for real wages. The VD of the forecast errors suggest that the contribution of real shocks is larger than that of nominal shocks in explaining real exchange rates for the Netherlands and the UK, whereas for France, the contribution is more or less the same between the two shocks, and for Italy, the real exchange rates are more fully explained by monetary shocks.

All these findings imply that where real shocks explain more of the real exchange rate fluctuations, they also contribute to explaining more of the real wage fluctuations. If real shocks affect the real exchange rate, then there is an impact on international competitiveness, necessitating changes in output, which are likely to affect the real wage rate.

\section{Unemployment and Wage Flexibility}

It has been empirically demonstrated that there is a strong, significant correlation between wage flexibility and unemployment in studies of the wage curve (Card, 1995). It is then reasonable to examine if there is any relationship between the real

wage flexibility claimed based on the variance decomposition results ${ }^{11}$ and 
unemployment conditions for these countries. Figure 5 shows the actual rate of unemployment, which is plotted with a linear trend line and also the deviation from the trend, and Table 4 presents the mean rate of unemployment and maximum, minimum and standard deviation of the deviations from the trend ${ }^{12}$. The noticeable difference between the developed economies and the transition economies is that the developed EU countries have a broadly downward trend line, whereas most CEECs have an upward trend (except Hungary). Poland and Slovakia show a relatively high unemployment rate with the peak of around $20 \%$ in the early 2000 s, which is accompanied by a considerable deviation from the trend with a standard deviation of around 1.9 as shown in Table 4.

The increase in the rate of unemployment in the CEECs over the last decade suggests that as the transition from a controlled to a market-determined economy proceeds, there is a temporary loss of price competitiveness relative to the developed EU countries, due to the temporary immobility of labor between the rising and traditional, declining sectors ${ }^{13}$. Boeri and Burda (1996), Burda and Profit (1966), Profit and Sperlich (1998) and Munich et al. (1998) have modelled the inflexibility of the job market in the Czech Republic and Slovakia, using the 'matching functions approach' where it takes time for a worker to find a suitable vacancy because of transaction costs associated with, for example, regional disparities or skill mismatch. A lack of well-functioning financial markets may further exacerbate labor immobility, where workers cannot borrow money for house purchase in a different region and workers cannot easily borrow money to start new businesses. There is also evidence that at the outset of the transition, policies aimed at making unemployment compensation more generous, provided opportunities for the unemployed to exploit the position by earning in the informal sector (Bouev, 2002). In the case of Hungary, 
the size of the informal economy notwithstanding, these factors seem to have been weaker than in the other CEECs, in that there is a decay in the measured rate of unemployment over the sample.

Amongst the developed EU countries, Italy and France have a relatively higher unemployment rate than the Netherlands and the UK. For Italy, the deviation from the trend appears to be quite large, although recent estimates suggest that Italy has a very large informal sector, perhaps amounting to 28\% of GDP (Schneider, 2000 and Schneider and Enste, 2000). Table 4 indicates that the standard deviation from the trend is at 0.90. (Note that the rate of unemployment in Netherlands deviates quite significantly, however, with the relatively low rates of unemployment it is not a major concern.) The contribution of real shocks on real wages is found to be insignificant in Italy and Poland. This may explain the higher rate of unemployment and a relatively large deviation from trend in these two countries, but in part it may also reflect the size of the informal sector in these economies, especially in Italy $^{14}$. It can be postulated that due to less sensitivity to real shocks, real wages are more likely to be rigid and the labor market slower to adjust leaving the measured rate of unemployment above the trend.

Slovakia, however, shows both a high unemployment rate and a real wage variance that is largely accounted for by real shocks. Interestingly, although not reported in this paper, the VD reveals that $95 \%$ to $98 \%$ of the nominal wage fluctuations are also explained by the real shock ${ }^{15}$. This suggests that price-rigidity predominates in this economy and that the transformation of the economy into a market economy is perhaps proceeding only slowly ${ }^{16}$.

\section{Conclusions}


In the new enlarged EU labor markets will become more exposed to international competition that greater integration of product markets brings. Reallocations of labor between different sectors of the economies, reflecting changing patterns of comparative advantage with consequent effects on productivity is inevitable. Therefore, the greater the flexibility of EU labor markets the lower will be equilibrium EU rates of unemployment.

This paper has examined the flexibility of labor markets through an analysis of the real wage responsiveness to temporary and permanent shocks for selected EU countries by using a structural VAR model. The impulse response functions indicate that the real wage rates of most EU members responded positively to both nominal and real shocks, with the exception of Slovakia. In the study of variance decomposition, in all countries except Italy and Poland, real wages are largely explained by real shocks. The analysis shows that countries, in which real shocks are the major determinants of real wage fluctuations, tend to experience a relatively low rate of unemployment and relatively small deviations of the rate of unemployment from the trend. In Italy and Poland, where real wage fluctuations are largely explained by temporary shocks, there has been higher and more persistent unemployment, reflecting less flexible labor markets and in Italy a large informal sector. Slovakia is a unique case, in that the ineffectiveness of demand policy to affect either real or nominal wages rates has been associated with a relatively high and volatile rate of unemployment. Thus labor market disequilibria seem to persist longer in Italy, Poland and Slovakia.

The policy implication from this analysis is that the Czech Republic and Hungary are suitable candidates for membership of the Euro area, at least from the perspective of the degree of real wage flexibility, although for Poland and Slovakia 
the unemployment risks associated with less real wage flexibility are much greater. It is also interesting to note that Italy, although a founding member of the EU in the 1950s, still seems to have rather inflexible labor markets and a very large shadow economy. This suggests that at least in practice Euro-area membership should not just depend on the nominal Maastricht criteria, but also on the degree of labor market flexibility. Moreover, on this broader criterion some of the new members states maybe better candidates than some existing member states. 


\section{References}

Andersen, Torben M., Sorensen, Jan R., 2000. Product market integration and wage formation. Journal of Economic Integration 15, 281-293.

Andersen, Torben M., Toulemonde, Eric, 2002. Imperfectly competitive labor markets and the productivity puzzle. Economics Letters 75, 115-122.

Blanchard, Olivier J., Quah, Danny, 1989. The dynamic effects of aggregate demand and supply disturbances. American Economic Review 79, 655-673.

Boeri, Tito, Burda, Michael C., 1996. Central and Eastern European labor markets: Active labor market policies, job matching and the Czech miracle. European Economic Review 40, 805-817.

Boeri, Tito, Garibaldi, Pietro, 2002. Shadow activity and unemployment in depressed labor markets. Centre for Economic Policy Research, London. Discussion Paper Series No. 3433.

Bouev, Maxim, 2002. Official regulations and the shadow economy: a labor market approach. William Davidson Institute Working Paper, No. 524.

Brada, Josef C., 1998. Introduction: Exchange rates, capital flows and commercial policies in transition economies. Journal of Comparative Economics 26, 613620.

Burda, Michael C., Profit, Stefan, 1996. Matching across space: Evidence on mobility in the Czech Republic. Labor Economics 3, 255-278.

Card, David, 1995. The wage curve: A review. Journal of Economic Literature 33, 785-799. 
Desai, Padma, 1998. Macroeconomic fragility and exchange rate vulnerability: A cautionary record of transition economies. Journal of Comparative Economics 26, 621-641.

Dibooglu, Selahttin, Kutan, Ali M., 2001. Sources of real exchange rate fluctuations in transition economies: The case of Poland and Hungary. Journal of Comparative Economics 29, 257-275.

Eilat, Yair, Zinnes, Clifford F., 2002. The shadow economy in transition economies: Friend or foe? A policy perspective. World Development 30, 1233-1254.

Enders, Walter, Lee, Bong S., 1997. Accounting for real and nominal exchange rate movements in the post-Bretton Woods period. Journal of International Money and Finance 16, 233-244.

Engle, Robert F., Granger, Clive W.J., 1987. Cointegration and error correction: representation, estimation and testing. Econometrica 55, 251-276.

Engle, Robert F., Yoo, Byung S., 1987. Forecasting and testing in cointegrated Systems. Journal of Econometrics 35, 143-159.

Evans, Martin D.D., Lothian, James R., 1993. The response of exchange rates to permanent and transitory shocks under floating exchange rates. Journal of International Money and Finance 12, 563-583.

Fardmanesh, Mohsen, Tan, Li, 2003. Wage and price control policies in transition economies. Journal of Development Economics 70, 173-200.

Gamber, Edward N., Joutz, Frederick L., 1993. The dynamic effects of aggregate demand and supply disturbances: Comment. American Economic Review 83, 1387-1393. 
Grubb, David R. and Layard, Richard, G., 1983. Wage rigidity and unemployment in OECD countries. European Economic Review 21, 11-39.

Hansen, Bruce E., 2001. The new econometrics of structural change: Dating breaks in U.S. labor productivity. Journal of Economic Perspectives 154, 117-128.

Heijdra, Ben, Van Der Ploeg, Frederick, 2002. Foundations of Modern Macroeconomic Analysis. Oxford University Press, Oxford.

Huber, Peter, 2004. Intra-national labor market adjustment in the candidate countries. Journal of Comparative Economics 32, 248-264.

Iara, Anna, Traistaru, Lulia, 2004. How flexible are wages in EU accession countries? Labor Economics 11, 431-450.

Kempa, Bernd, 2000. Excess volatility of real exchange rates in the EMS: Some evidence from structural VARs. Applied Economics 32, 73-79.

Kwiatkowski, Denis, Phillips, Peter, C.B., Schmidt, Peter, Shin, Yongcheol, 1992. Testing the null of stationarity against the alternative of a unit root: How sure are we that economic time series have a unit root? Journal of Econometrics 54, $159-178$

Lastrapes, William D., 1992. Sources of fluctuations in real and nominal exchange rates. Review of Economics and Statistics 74, 530-539.

Mankiw, N. Gregory, 1985. Small menu costs and large business cycles: A macroeconomic model of monopoly. Quarterly Journal of Economics 100, 529539.

Marcelliono, Massimiliano, Mizon, Graham E., 2000. Modelling shifts in the wageprice and unemployment-inflation relationships in Italy, Poland and the UK. Economic Modelling 17, 387-413. 
Montuenga-Gomez, Victor M., Garcia, Inmaculada, Fernandez, Melchor, 2003. Wage flexibility: Evidence from five EU countries based on the wage curve. Economics Letters 78, 169-174.

Munich, Daniel, Svejnar, Jan, Terrell, Katherine, 1998. The worker-firm matching in transition economies: Why are the Czechs more successful than others? The William Davidson Institute Working Papers, No. 107.

Papazoglou, Christos, Pentecost, Eric J., 2004. The dynamic adjustment of a transition economy in the early stages of transformation. Journal of Macroeconomics 26, $541-561$.

Pentecost, Eric J., Sessions, John G., 2002. Changing labor market flexibility in the European Union. Weltwirtshaftliches Archiv/Review of World Economics 138, 148-160.

Profit, Stefan, Sperlich, Stefan, 1998. Non-uniformity of job-matching in a transition economy a non-parametric analysis for the Czech Republic, Quantifikation and Simulation Okonomischer Prezesse, Humboldt-Universit zu Berlin, Discussion Paper, No.15.

Schneider, Friedrich, 2000. The growth of the shadow economy in the OECD: Some preliminary explanations. Journal of International Affairs 53, 413-432.

Schneider, Friedrich, Enste, Dominik H., 2000. Shadow economies: Size, causes and consequences. Journal of Economic Literature 38, 77-114.

Shapiro, Carl, Stiglitz, Joseph E., 1984. Equilibrium unemployment as a worker discipline device. American Economic Review 74, 433-444.

Spencer, David E., 1998. The relative stickiness of wages and prices. Economic Inquiry $36,120-137$. 
Figure 1: Distinguishing between Real and Nominal Shocks

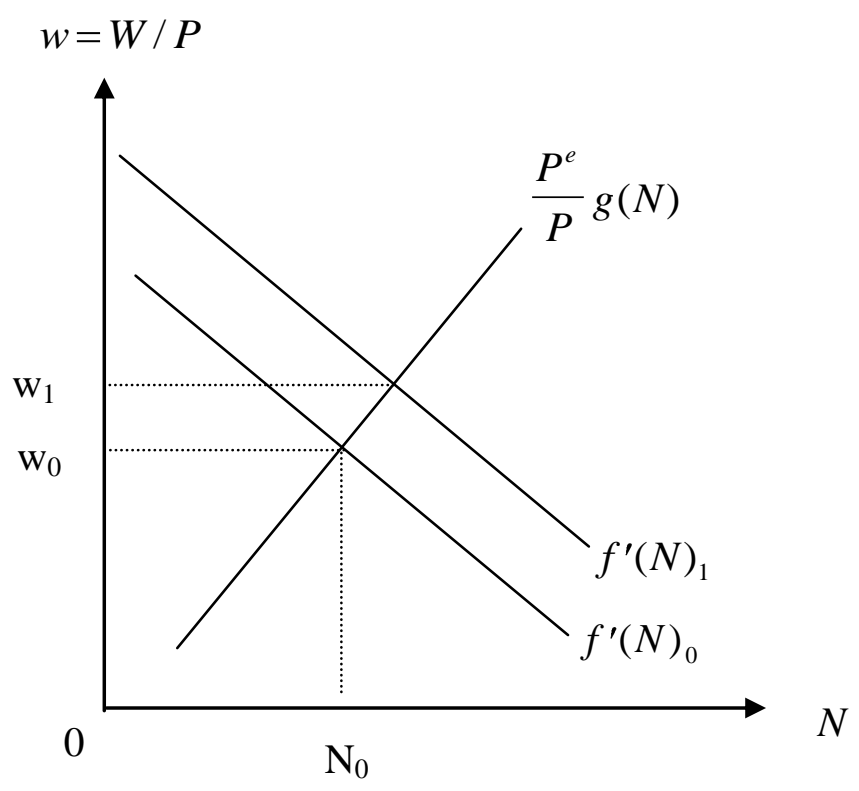


Figure 2 Plots of real and nominal wage rates

(solid line: log of real wage, dotted line: log of nominal wage)

France

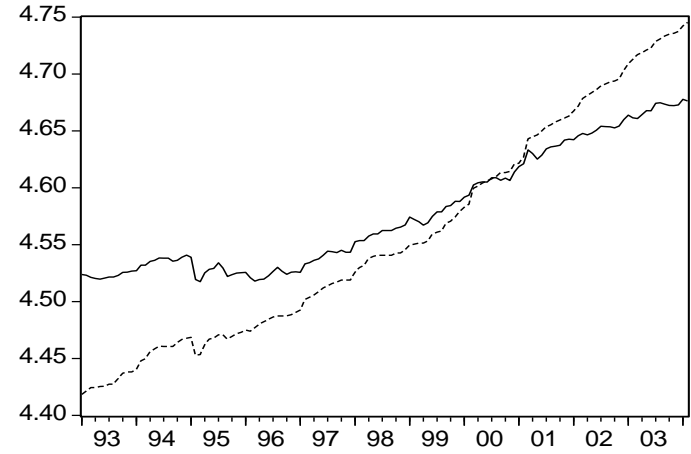

Netherlands

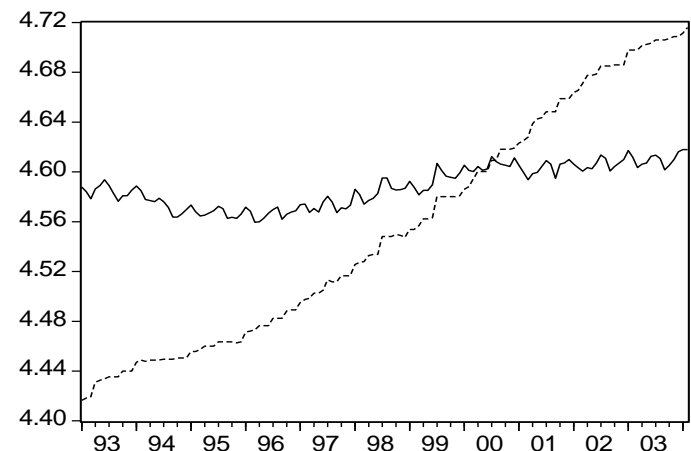

Czech

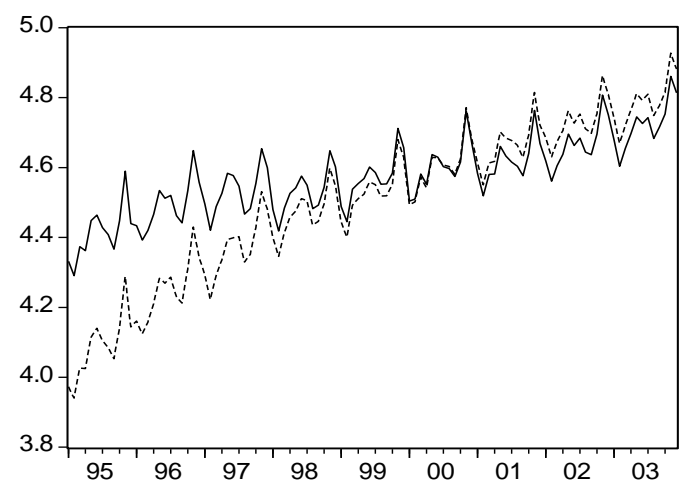

Poland

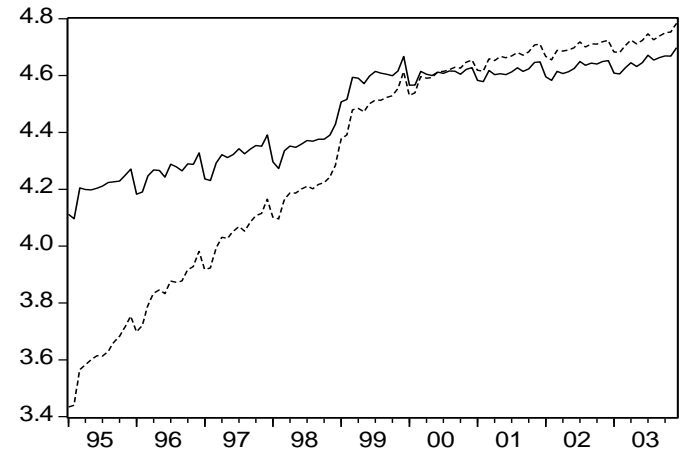

Italy

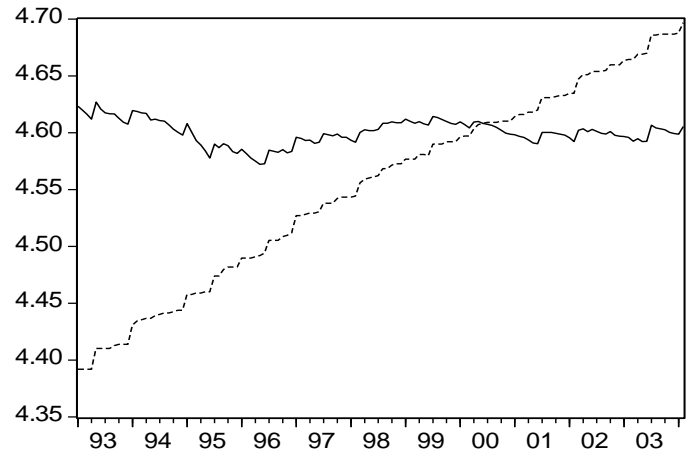

UK

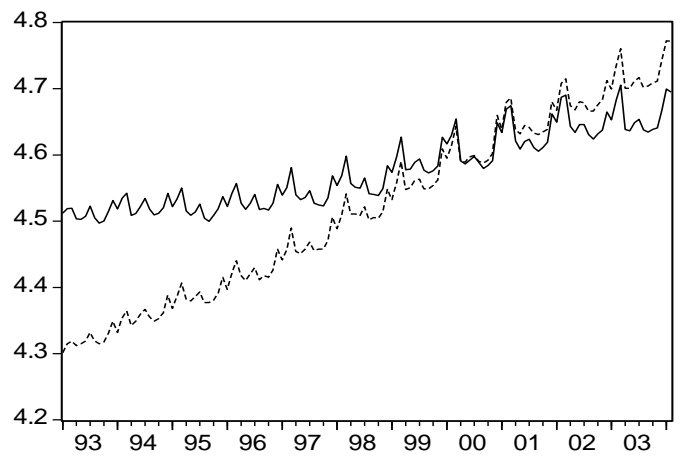

Hungary

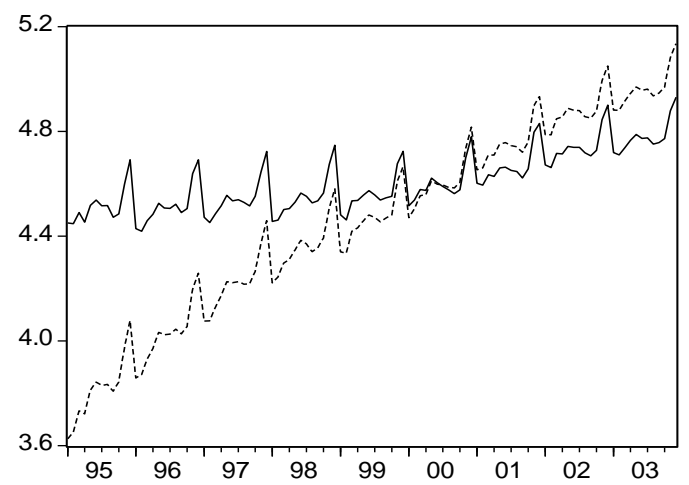

Slovakia

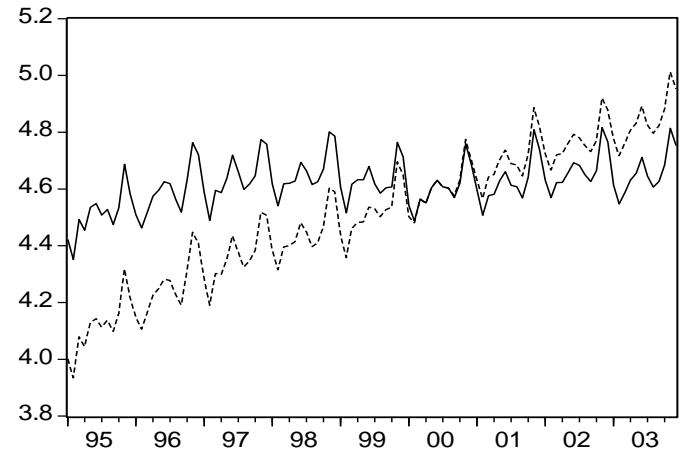


Figure 3: Impulse response functions: Response of real wage to one standard deviation innovations (- real shock, ---- nominal shock)

Real wage (France)

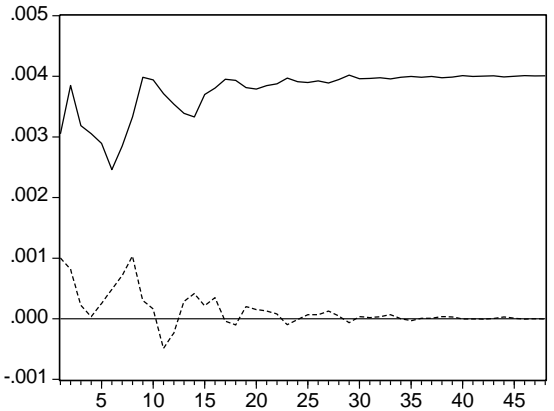

Real wage (Netherlands)

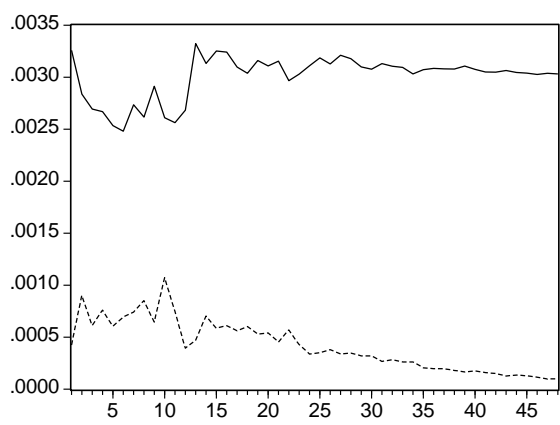

Real wage (Czech)

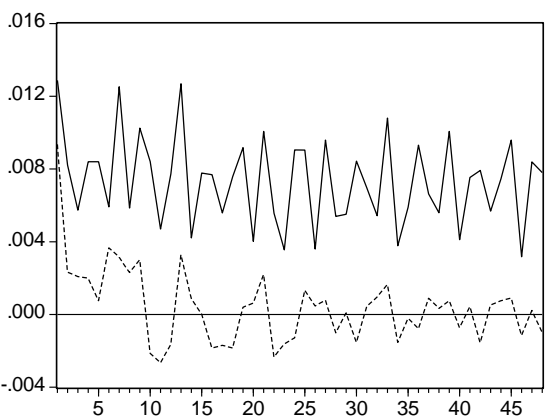

Real wage (Poland)

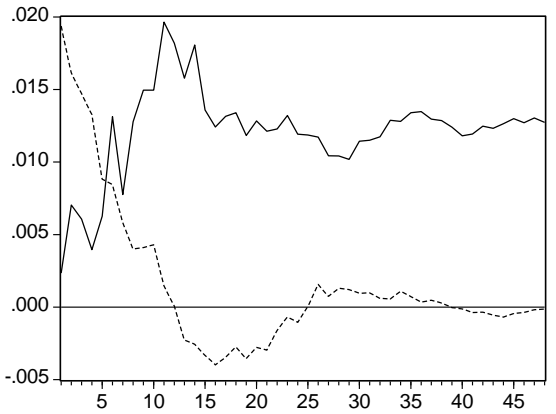

Real wage (Italy)

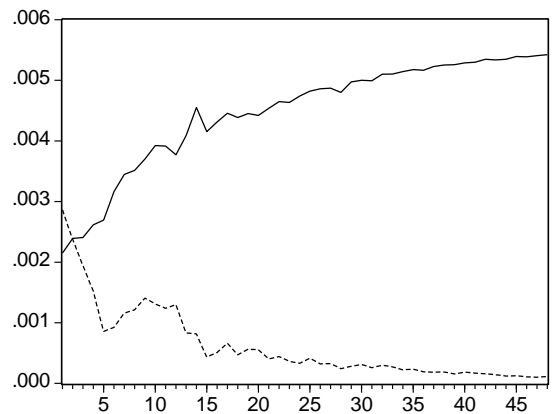

Real wage (UK)

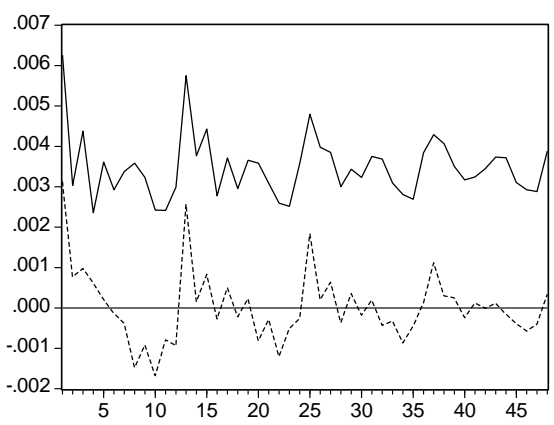

Real wage (Hungary)

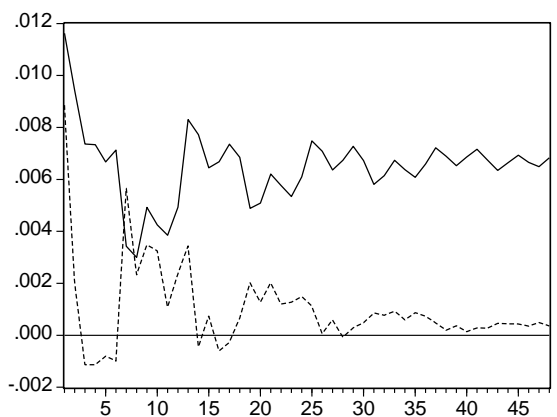

Real wage (Slovakia)

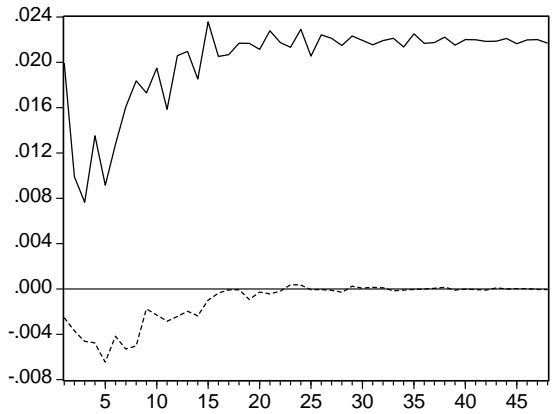

Notes.

a. Horizontal axes indicate months.

b. Wages are in logarithms. 
Figure 4: Impulse response functions: Response of nominal wage to one standard deviation innovations ( - real shock, ---- nominal shock)

Nominal wage (France)

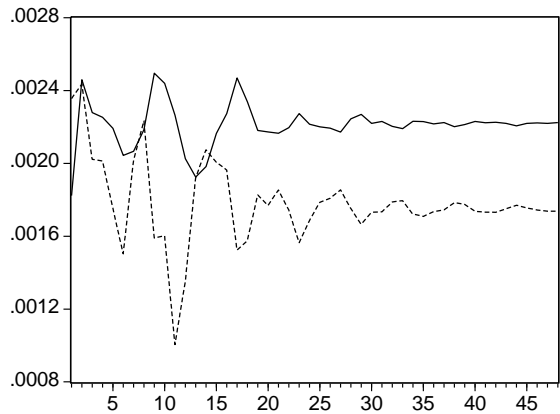

Nominal wage (Netherlands)

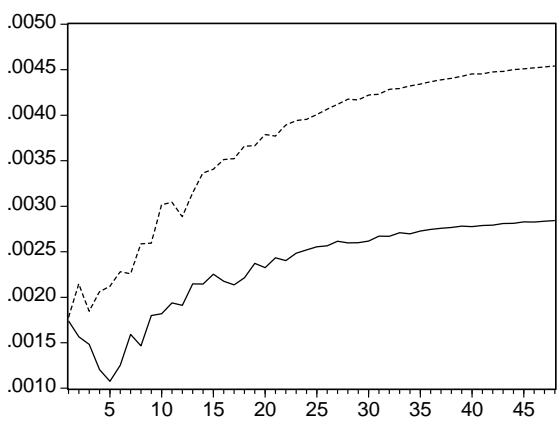

Nominal wage (Czech)

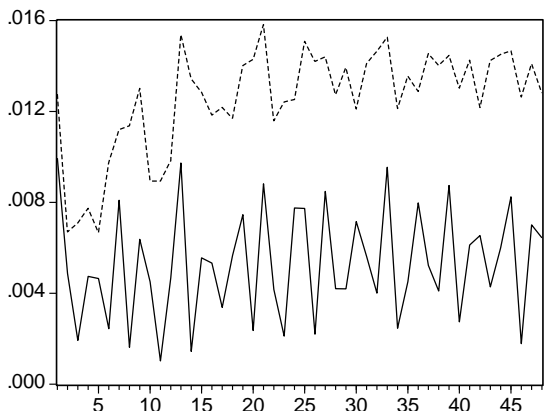

Nominal wage (Poland)

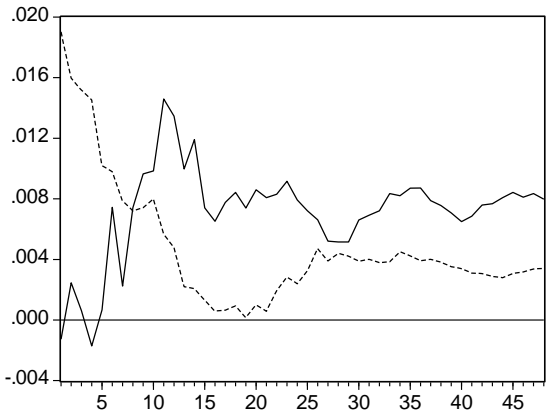

Nominal wage (Italy)

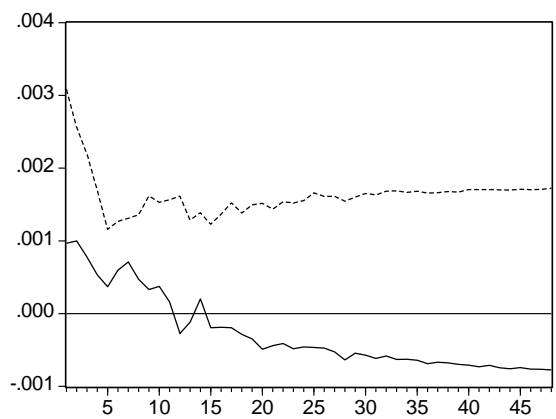

Nominal wage (UK)

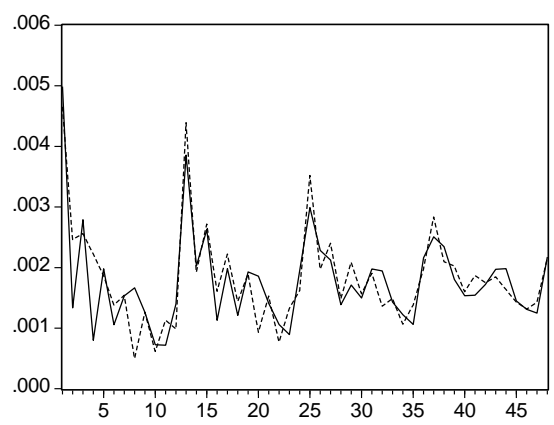

Nominal wage (Hungary)

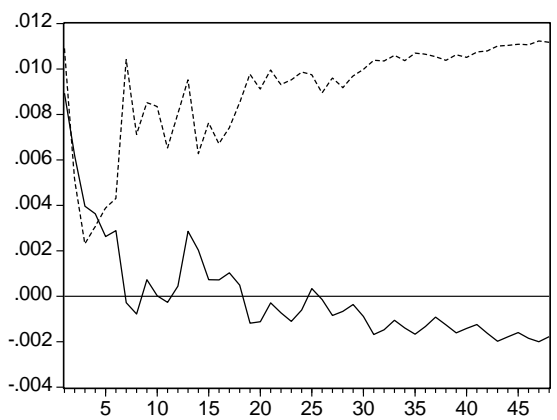

Nominal wage (Slovakia)

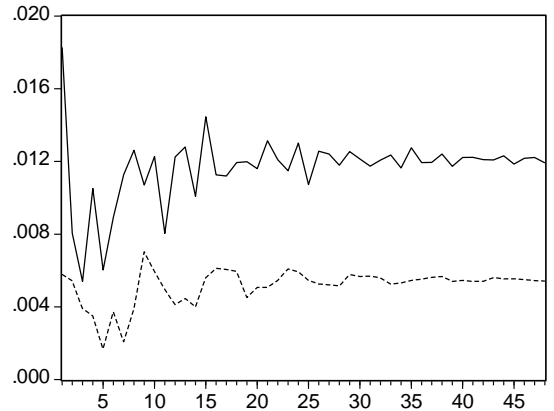

Notes.

a. Horizontal axes indicate months.

b. Wages are in logarithms. 
Figure 5: Unemployment rate and the deviation from trend
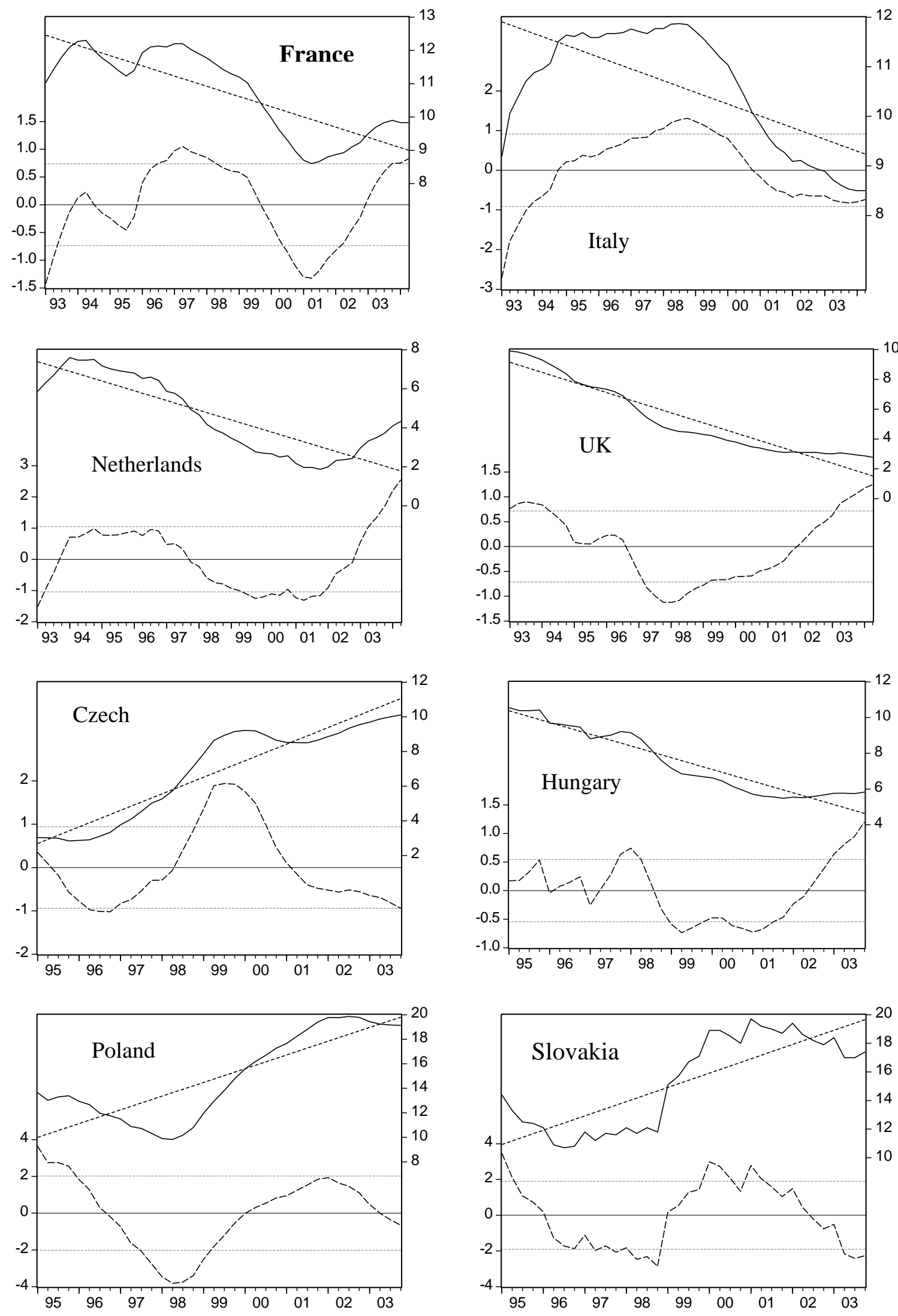

actual unemployment rate (\%) ------ time trend, --- the deviation from the trend (\%) with the left side scale. Sources. OECD Main Economic Indicators.

Note. Quarterly data are used for unemployment rate. 
Table 1 Unit root and cointegration tests

\section{Unit root tests}

$(r w=$ the $\log$ of real wage and $n w=$ the log of nominal wage $)$

\begin{tabular}{|l|l|l|l|l|l|}
\hline & $\begin{array}{l}\text { ADF constant } \\
(\mathrm{lag})\end{array}$ & $\begin{array}{l}\text { ADF constant } \\
\text { and trend (lag) }\end{array}$ & $\begin{array}{l}\text { KPSS constant } \\
(\mathrm{lag})\end{array}$ & $\begin{array}{l}\text { KPSS constant } \\
\text { and trend (lag) }\end{array}$ \\
\hline France & $r w$ & $1.388(2)$ & $1.725(2)$ & $1.352(9)$ & $0.328(9)$ \\
\hline & $n w$ & $2.179(0)$ & $1.068(0)$ & $1.415(9)$ & $0.350(9)$ \\
\hline Italy & $r w$ & $2.209(6)$ & $2.155(6)$ & $0.148(9) *$ & $0.150(9)$ \\
\hline & $n w$ & $1.509(6)$ & $1.683(6)$ & $1.438(9)$ & $0.334(9)$ \\
\hline Netherlands & $r w$ & $0.274(12)$ & $3.257(12)$ & $1.146(9)$ & $0.219(9)$ \\
\hline & $n w$ & $0.306(12)$ & $3.279(12)$ & $1.429(9)$ & $0.315(9)$ \\
\hline UK & $r w$ & $0.441(13)$ & $2.386(13)$ & $1.410(9)$ & $0.251(6)$ \\
\hline & $n w$ & $0.367(13)$ & $1.963(13)$ & $1.451(9)$ & $0.126(4) *$ \\
\hline Czech & $r w$ & $0.635(14)$ & $2.754(14)$ & $1.261(8)$ & $0.132(38) *$ \\
\hline & $n w$ & $1.505(14)$ & $3.368(14)$ & $1.280(8)$ & $0.372(5)$ \\
\hline Hungary & $r w$ & $0.965(14)$ & $0.779(14)$ & $1.215(8)$ & $0.340(1)$ \\
\hline & $n w$ & $1.523(14)$ & $2.338(14)$ & $1.183(9)$ & $0.319(5)$ \\
\hline Poland & $r w$ & $1.442(14)$ & $1.948(12)$ & $1.106(9)$ & $0.214(8)$ \\
\hline & $n w$ & $2.169(14)$ & $0.743(14)$ & $1.131(9)$ & $0.285(9)$ \\
\hline Slovakia & $r w$ & $2.841(16)$ & $3.118(16)$ & $0.956(4)$ & $0.207(3)$ \\
\hline & $n w$ & $1.387(16)$ & $2.899(16)$ & $1.308(8)$ & $0.164(8)$ \\
\hline
\end{tabular}

\section{Engle-Granger Cointegration tests}

\begin{tabular}{|l|l|l|}
\hline & ADF constant (lag) & ADF constant and trend (lag) \\
\hline France & $2.018(0)$ & $2.011(0)$ \\
\hline Italy & $2.666(0)$ & $2.660(0)$ \\
\hline Netherlands & $2.370(12)$ & $2.464(12)$ \\
\hline UK & $2.934(12)^{*}$ & $2.906(12)$ \\
\hline Czech & $1.880(13)$ & $1.119(12)$ \\
\hline Hungary & $0.074(14)$ & $2.245(12)$ \\
\hline Poland & $2.878(0)$ & $2.858(0)$ \\
\hline Slovakia & $1.906(0)$ & $1.896(0)$ \\
\hline
\end{tabular}

\begin{tabular}{|l|l|l|l|l|}
\hline Critical Values & ADF constant & $\begin{array}{l}\text { ADF constant } \\
\text { and trend }\end{array}$ & KPSS constant & $\begin{array}{l}\text { KPSS constant } \\
\text { and trend }\end{array}$ \\
\hline Null & Unit root & Unit root & Stationarity & Stationarity \\
\hline $1 \%$ & 2.890 & 4.046 & 0.739 & 0.216 \\
\hline $5 \%$ & 2.860 & 3.452 & 0.463 & 0.146 \\
\hline $10 \%$ & 2.582 & 3.151 & 0.347 & 0.119 \\
\hline
\end{tabular}

Notes.
a. The symbol $*$ represents statistical significance at the $5 \%$ level, where the null is rejected in the case of ADF, and not rejected in the in the case of KPSS.

b. ADF (Augmented Dickey Fuller) critical value is from Engle and Yoo (1987).

c. KPSS (Kwiatkowski-Phillips-Schmidt-Shin) critical value is from Kwiatkowski, Phillips, Schmidt and Shin (1992).

d. Akaike Information Criteria and Newly-West Bandwidth are used for the choice of lag length for the ADF and KPSS with the maximum lag 16.

e. The Engle-Granger cointegration tests are conducted by regressing $r w$ on constant, trend and $n w$ except Italy where the trend is excluded as it is insignificant at a 5\% level. 
Table 2 VAR Modelling

\begin{tabular}{|l|l|l|}
\hline & Lag length & Trend (T) and dummies \\
\hline France & 11 & T, M2, M8, M9 \\
\hline Italy & 14 & M1, M2, M3, M4, M5, M6, M8, M9, M10, M11, M12 \\
\hline Netherlands & 12 & M2, M3, M4, M5, M6, M8, M9, M10, M11, M12 \\
\hline UK & 13 & D1, M3, M4, M5, M8 \\
\hline Czech & 12 & D1, D3, M1, M2, M11 \\
\hline Hungary & 12 & M1, M8, M11, M12 \\
\hline Poland & 13 & D2, T, M1, M5 \\
\hline Slovakia & 11 & M1, M2, M8, M11
\end{tabular}

Notes.

a. Sample period for France, Italy, Netherlands and UK is from 1993:1 to 2004:2 (134 observations), and for Czech, Hungary, Poland and Slovakia from 1995:1 to 2003:12 (108 observations).

b. M indicates monthly dummy (e.g. M1, dummy 1 for January and dummy 0 otherwise).

Likelihood ratio tests of period-specific dummies

\begin{tabular}{|l|l|l|}
\hline D1 & $\begin{array}{l}\text { Asian and Russian crises: } \\
\text { Floating regime in Czech: } \\
\text { dummy 1 for 1997:5-1998:8 and dummy 0 otherwise }\end{array}$ & $\begin{array}{l}\text { France 1.81, Italy 2.63, } \\
\text { Netherlands 2.44, UK 9.17*, } \\
\text { Czech 8.78*, Hungary 4.58, } \\
\text { Poland 3.86, Slovakia 0.44 }\end{array}$ \\
\hline D2 & $\begin{array}{l}\text { Inflation targeting in Poland: } \\
\text { dummy 1 from 1998:9 onward and dummy 0 otherwise }\end{array}$ & Poland 6.90* \\
\hline D3 & $\begin{array}{l}\text { Inflation targeting in Czech: } \\
\text { dummy 1 from 1998:1 onward and dummy 0 otherwise }\end{array}$ & Czech 8.07* \\
\hline
\end{tabular}

Note.

The symbol * represents statistical significance at the $5 \%$ level with the critical value of $5.99(\mathrm{df}=2)$. 
Table 3: Variance Decomposition of Real Wages (relative contribution of real shock in \%)

\begin{tabular}{|c|c|c|c|c|c|c|c|c|}
\hline \multicolumn{2}{|r|}{ France } & \multicolumn{2}{|r|}{ Italy } & \multicolumn{2}{|c|}{ Netherlands } & \multicolumn{3}{|c|}{ UK } \\
\hline $\mathrm{k}$ & Real wage & s.e. & Real wage & s.e. & Real wage & s.e. & Real wage & s.e. \\
\hline 1 & 90.213 & $(0.003)$ & 36.060 & $(0.004)$ & 98.324 & $(0.003)$ & 80.018 & $(0.007)$ \\
\hline 3 & 88.136 & $(0.003)$ & 35.186 & $(0.004)$ & 95.631 & $(0.003)$ & 76.957 & $(0.008)$ \\
\hline 6 & 87.367 & $(0.003)$ & 34.856 & $(0.004)$ & 95.187 & $(0.003)$ & 78.444 & $(0.009)$ \\
\hline 9 & 83.672 & $(0.004)$ & 35.174 & $(0.004)$ & 94.785 & $(0.003)$ & 76.930 & $(0.009)$ \\
\hline 12 & 80.810 & $(0.004)$ & 35.441 & $(0.004)$ & 91.612 & $(0.003)$ & 75.849 & $(0.009)$ \\
\hline 18 & 78.335 & $(0.004)$ & 36.650 & $(0.004)$ & 91.370 & $(0.004)$ & 65.415 & $(0.011)$ \\
\hline 24 & 77.672 & $(0.004)$ & 36.725 & $(0.004)$ & 91.021 & $(0.004)$ & 64.412 & $(0.011)$ \\
\hline 36 & 77.449 & $(0.004)$ & 36.882 & $(0.004)$ & 90.970 & $(0.004)$ & 60.828 & $(0.012)$ \\
\hline \multirow[t]{2}{*}{48} & 77.434 & $(0.004)$ & 36.917 & $(0.004)$ & 90.958 & $(0.004)$ & 60.237 & $(0.012)$ \\
\hline & Czech & & Hungary & & Poland & & Slovakia & \\
\hline $\mathrm{k}$ & Real wage & s.e. & Real wage & s.e. & Real wage & s.e. & Real wage & s.e. \\
\hline 1 & 70.583 & $(0.014)$ & 63.266 & $(0.015)$ & 1.442 & $(0.020)$ & 90.887 & $(0.019)$ \\
\hline 3 & 59.678 & $(0.017)$ & 51.663 & $(0.017)$ & 6.857 & $(0.020)$ & 92.538 & $(0.022)$ \\
\hline 6 & 59.111 & $(0.018)$ & 51.748 & $(0.017)$ & 17.232 & $(0.022)$ & 91.986 & $(0.023)$ \\
\hline 9 & 66.263 & $(0.020)$ & 45.866 & $(0.019)$ & 25.536 & $(0.024)$ & 89.577 & $(0.024)$ \\
\hline 12 & 63.976 & $(0.020)$ & 45.316 & (0.019) & 28.107 & $(0.024)$ & 89.809 & $(0.025)$ \\
\hline 18 & 65.034 & $(0.022)$ & 44.927 & $(0.020)$ & 31.501 & $(0.025)$ & 89.954 & $(0.026)$ \\
\hline 24 & 66.161 & $(0.023)$ & 45.344 & $(0.020)$ & 31.981 & $(0.025)$ & 89.653 & $(0.026)$ \\
\hline 36 & 68.201 & $(0.025)$ & 45.741 & $(0.020)$ & 32.243 & $(0.026)$ & 89.734 & $(0.026)$ \\
\hline 48 & 69.735 & $(0.025)$ & 45.908 & $(0.020)$ & 32.394 & $(0.026)$ & 89.736 & $(0.026)$ \\
\hline
\end{tabular}

a. ' $\mathrm{k}$ ' indicates forecast horizon in months.

b. Wages are in a differenced logarithm.

c. The contribution of nominal shock is $100 \%$ minus the contribution of real shock 
Table 4 The mean rate of unemployment and the deviations from the time trend

\begin{tabular}{lrrrr}
\hline & France & \multicolumn{1}{c}{ Italy } & Netherlands & \multicolumn{1}{c}{ UK } \\
\hline Mean & 10.729 & 10.571 & 4.587 & 5.331 \\
Maximum & 1.049 & 1.309 & 2.545 & 1.246 \\
Minimum & -1.425 & -2.714 & -1.519 & -1.124 \\
S.D. & 0.730 & 0.904 & 1.033 & 0.706 \\
\hline
\end{tabular}

\begin{tabular}{lrrrr}
\hline & Czech & \multicolumn{1}{c}{ Hungary } & \multicolumn{1}{c}{ Poland } & Slovakia \\
\hline Mean & 6.871 & 7.504 & 14.898 & 15.292 \\
Maximum & 1.940 & 1.199 & 3.644 & 3.477 \\
Minimum & -1.022 & -0.736 & -3.817 & -2.868 \\
S.D. & 0.926 & 0.537 & 1.987 & 1.872 \\
\hline
\end{tabular}

Notes.

a. The sample period is 1993-2003 for developed economies and 1995-2003 for transition economies

b. All figures are in percentages.

c. Mean implies the mean rate of unemployment based on quarterly unemployment rate.

d. Maximum, Minimum and S.D. are based on deviations from the time trend. 


\section{Acknowledgements}

The authors are grateful to John Bonin and two anonymous referees, Michael Bergman (University of Copenhagen) and also John Sessions (University of Bath), for constructive and helpful comments in the revision of this paper.

\section{Endnotes}

${ }^{1}$ Huber's sample was based on annual, regional data and included Bulgaria, The Czech Republic, Estonia, Hungary, Poland, Romania and Slovenia. Iara and Traistaru (2004) also found that regional average earnings adjusted to local unemployment rates in Bulgaria, Hungary and Poland.

${ }^{2}$ For example, Andersen and Toulemonde (2002), using a dynamic, monopoly union model where the managers of the firm have the right to mange, conclude that permanent productivity shocks lead to permanent increases in the real wage with little effect on employment, whereas temporary shocks are consistent with little real wage responsiveness. Similarly, the efficiency wage models of the Shapiro-Stiglitz variety (Shapiro and Stiglitz, 1984), suggest that permanent rises in productivity lead to increases in the real wage rate, whereas temporary nominal shocks have little effect on the real wage rate.

${ }^{3}$ At the microeconomic level this could be the result of menu costs (Mankiw, 1985), where although the general price level is rising, firms are reluctant to change their output prices because of the costs involved.

${ }^{4}$ Note that even with the model $[\Delta r w, \Delta p]$, instead of $[\Delta r w, \Delta n w]$, the contribution of real shocks in the variance decomposition of the real wage would be the same, because real shocks have no long-run effect on the level of prices or nominal wages, but can have a long-run effect on the level of real wages. 
${ }^{5}$ The symmetry of the system is such that $\sigma_{21}=\sigma_{12}$.

${ }^{6}$ Since for both wages and CPI, the base year is 2000 , the real and nominal wages plots intersect in 2000 .

${ }^{7}$ Hansen (2001) argues that an important limitation of Chow's structural break tests is that the break date must be known a priori. However, since this is not normally the case, following Debooglu and Kutan (1998), a break date is selected based on some known feature of the data and the significance tested. This is to exogenously identify the dates for structural breaks, which are assumed to be based on a specific event or policy change and not for the occurrence of a decisive break. We are thankful to an anonymous referee for this point.

${ }^{8}$ For example, the early part of the sample period for the developed countries is closer to that of a flexible regime with the experience of loosened ERM (European Rate Mechanism) parity grid after the EMS (European Monetary system) currency crises of 1992-93 (Kempa 2000). In the case of the transition economies during the sample period, for Czech Republic, Poland and Slovakia the exchange rate regime is, more or less, characterised by the fixed rather than floating regime as they adopted a managed floating policy. In Hungary, the policy of a crawling peg was combined with bands of more than $\pm 1 \%$ in practice.

${ }^{9}$ Anderson and Sorensen (2000) modelled a time varying wage convergence model by comparing the domestic real product wage to the foreign real product wage. The result supports the view that increased economic integration induces a potential wage convergence among the member states.

${ }^{10}$ In their study of the US, Gamber and Joutz (1993) and Spencer (1998) also found that the total real shock accounted for most of the forecast error variance for real wages, ranging from around $75 \%$ to $95 \%$. 
${ }^{11}$ Note that we are assuming that real wages, which are explained by real shocks are more flexible than those explained by nominal shocks.

12 The link between official or measured unemployment and actual unemployment is weakened by the estimated existence of a substantial shadow economy in these economies. Recent work by Schneider (2000) and Schneider and Enste (2000) estimate that the shadow economy maybe as much as 39\% of GDP in Hungary. For most EU members it is estimated to lie between $13 \%$ and $16 \%$ of GDP, with Italy (28\%) and Czech Republic (24\%) the exceptions. The existence of a shadow economy may also make any relationship between measured unemployment and real wages more opaque.

13 Under the planning system, labor had been allocated through administrative measures for decade (Fardmanesh and Tan, 2003).

${ }^{14}$ Indeed, it may be partly due to the rigidity of wages that a large informal sector has developed.

${ }^{15}$ For other EU countries, variability in nominal wages is mainly driven by nominal shocks. For France, Italy, Netherlands, Hungary and Poland, the nominal shock accounts for more than $50 \%$ of nominal wage variability. For the UK and the Czech Republic, the nominal shock accounts for between $37 \%$ (time horizon $\mathrm{k}=3$ ) to $48 \%$ $(\mathrm{k}=48)$ and from $29 \%(\mathrm{k}=48)$ to $62 \%(\mathrm{k}=1)$ respectively, of nominal wage fluctuations. The results are available on request from the authors.

${ }^{16}$ Spencer (1998) argues that the failure of nominal wages to adjust in the short run to nominal disturbances may explain why employment temporarily deviates from the natural rate. Grubb et al. (1983) also argue that while real wage rigidity is often blamed for causing unemployment in the wake of adverse real shocks, such as changes in productivity or the terms of trade, nominal wage rigidity is blamed for 
causing unemployment in the wake of adverse nominal shocks, like falls in nominal demand. 